\title{
An Aggregate of Spear Points from Atoka County, Oklahoma
}

Robert L. Brooks

Unknown

Follow this and additional works at: https://scholarworks.sfasu.edu/ita

Part of the American Material Culture Commons, Archaeological Anthropology Commons, Environmental Studies Commons, Other American Studies Commons, Other Arts and Humanities Commons, Other History of Art, Architecture, and Archaeology Commons, and the United States History Commons

Tell us how this article helped you.

This Article is brought to you for free and open access by the Center for Regional Heritage Research at SFA ScholarWorks. It has been accepted for inclusion in Index of Texas Archaeology: Open Access Gray Literature from the Lone Star State by an authorized editor of SFA ScholarWorks. For more information, please contact cdsscholarworks@sfasu.edu. 


\section{An Aggregate of Spear Points from Atoka County, Oklahoma \\ Creative Commons License \\ (c) $($ ) (9)}

This work is licensed under a Creative Commons Attribution-NonCommercial 4.0 International License 


\title{
AN Aggregate of SPEAR Points From ATOKa COUNTY, OKLAHOMA
}

\section{Robert L. Brooks}

\begin{abstract}
Nine spear points were reported from a farm in northwestern Atoka County, Oklahoma. This aggregate of points appeared to bean isolate as no other prehistoric material was found in the vicinity. The following study discusses the setting and nature of the specimens, stylistic attributes of the spear points and their age, technological and functional characteristics of the pieces, and whether these items represent caching behavior.
\end{abstract}

\section{Introduction}

In the fall of 2013, a family from northern Atoka County reported a cluster of spear points found near their home (Figure 1). A subsequent photograph provided by the family revealed that these were large, basally-notched spear points. On October 27th 2013, I visited the family and examined the location where the materials were collected. They were very gracious in permitting me to photograph and analyze the specimens.

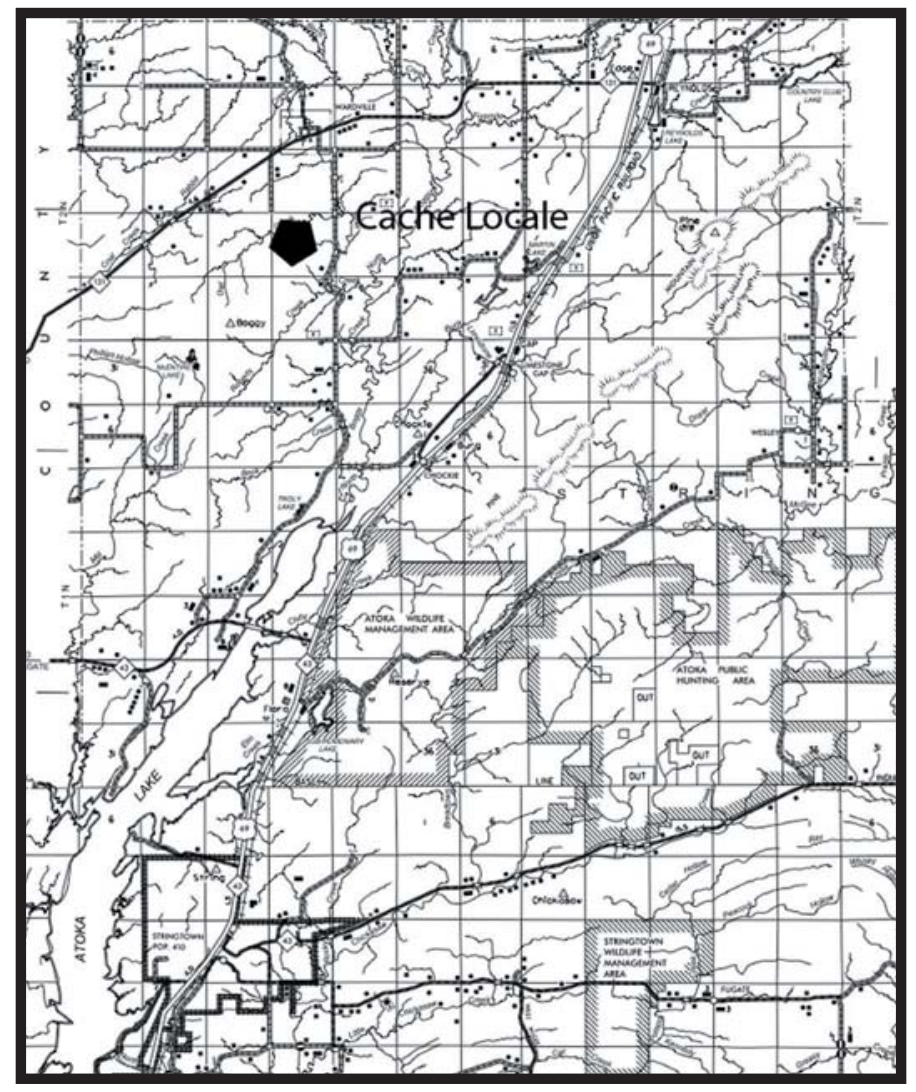

Figure 1. The location of the spear point aggregate in Atoka County. 


\section{Setting}

The location where the spear points were found is situated in the saddle of a north-south trending ridge (Figure 2). The setting presents a good vista of the surrounding landscape, especially to the west. It is also quite distant from water with an intermittent stream some 400 meters southeast. Dissected uplands and shallow stream valleys characterize the topography of northern Atoka County. It forms part of the McAlester Marginal Hills Belt that is comprised of Pennsylvanian-age sandstone and shales (Johnson 2006). Natural vegetation in the region is a Post Oak-Blackjack regime commonly referred to as the "Cross Timbers" (Hoagland 2006a). The Cross Timbers represent a mosaic of scrub forest areas interspersed by grasslands. However, here the native vegetation has been replaced by improved pasturelands. Accompanying soils are Mollisols that form under principally grassland conditions (Hoagland 2006b).

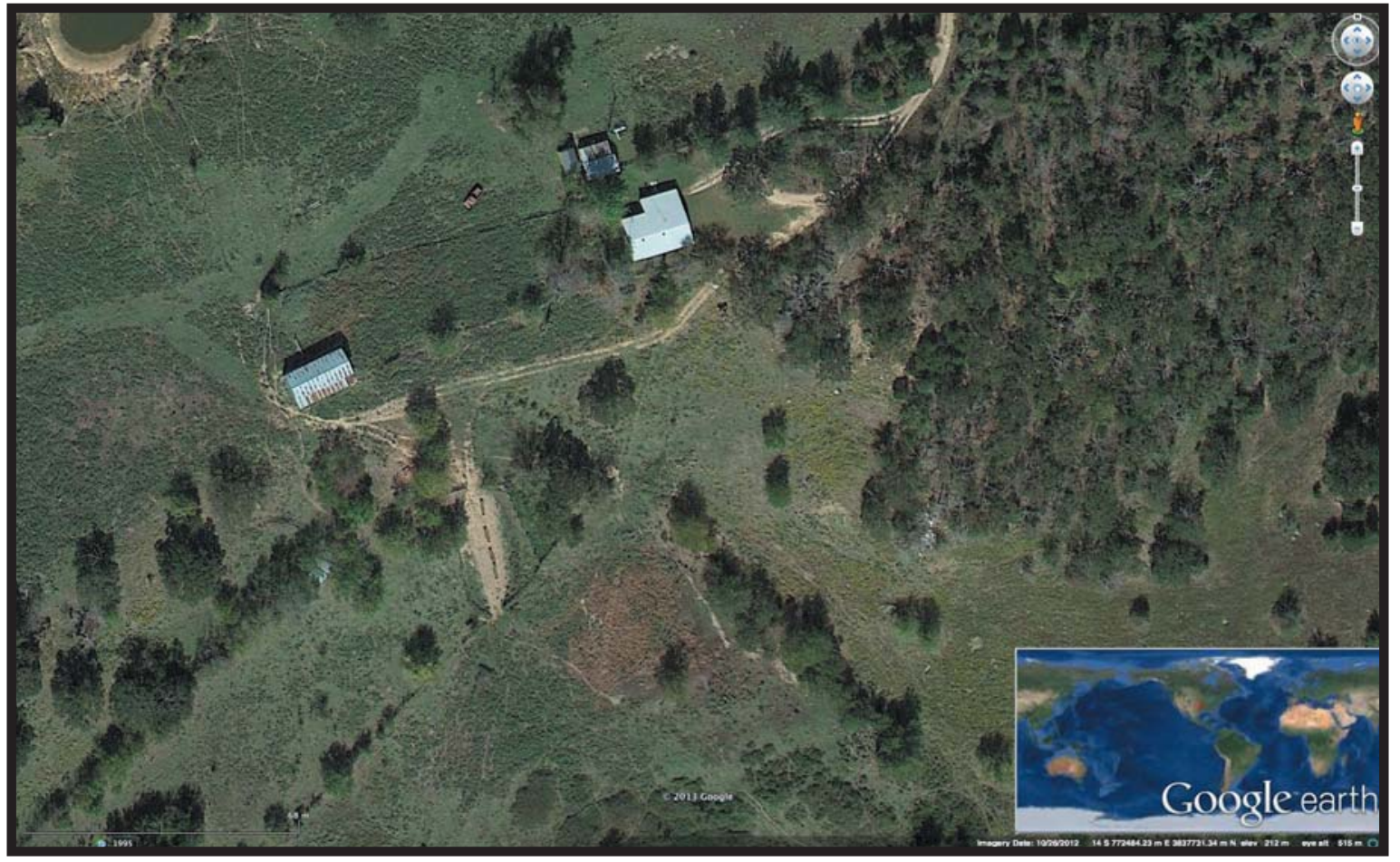

Figure 2. Setting of the artifacts in saddle area of ridge.

\section{Spear Point Cluster Context}

The cluster of spear points occur where cattle had been congregating around a salt block and churning the soil in an area roughly two meters in diameter (Figure 3). Upon seeing the artifacts in the churnedup area, family members worked through the loose soil finding six complete and three broken points. They were fairly thorough, recovering many of the fragments from the broken pieces. Family members describe the points as being present on the surface and only requiring removal of a few inches of soil to expose them. I reexamined the salt block locale and saw no evidence of additional points, point fragments, or other chipped stone debris. However, the exposed area was not excavated to attempt recovery of the small missing fragments. The surrounding areas of the ridge were also examined, but this canvassing failed to reveal any evidence of prehistoric material. It would appear that the cluster of spear points represents an isolated event and not part of larger prehistoric use area. 


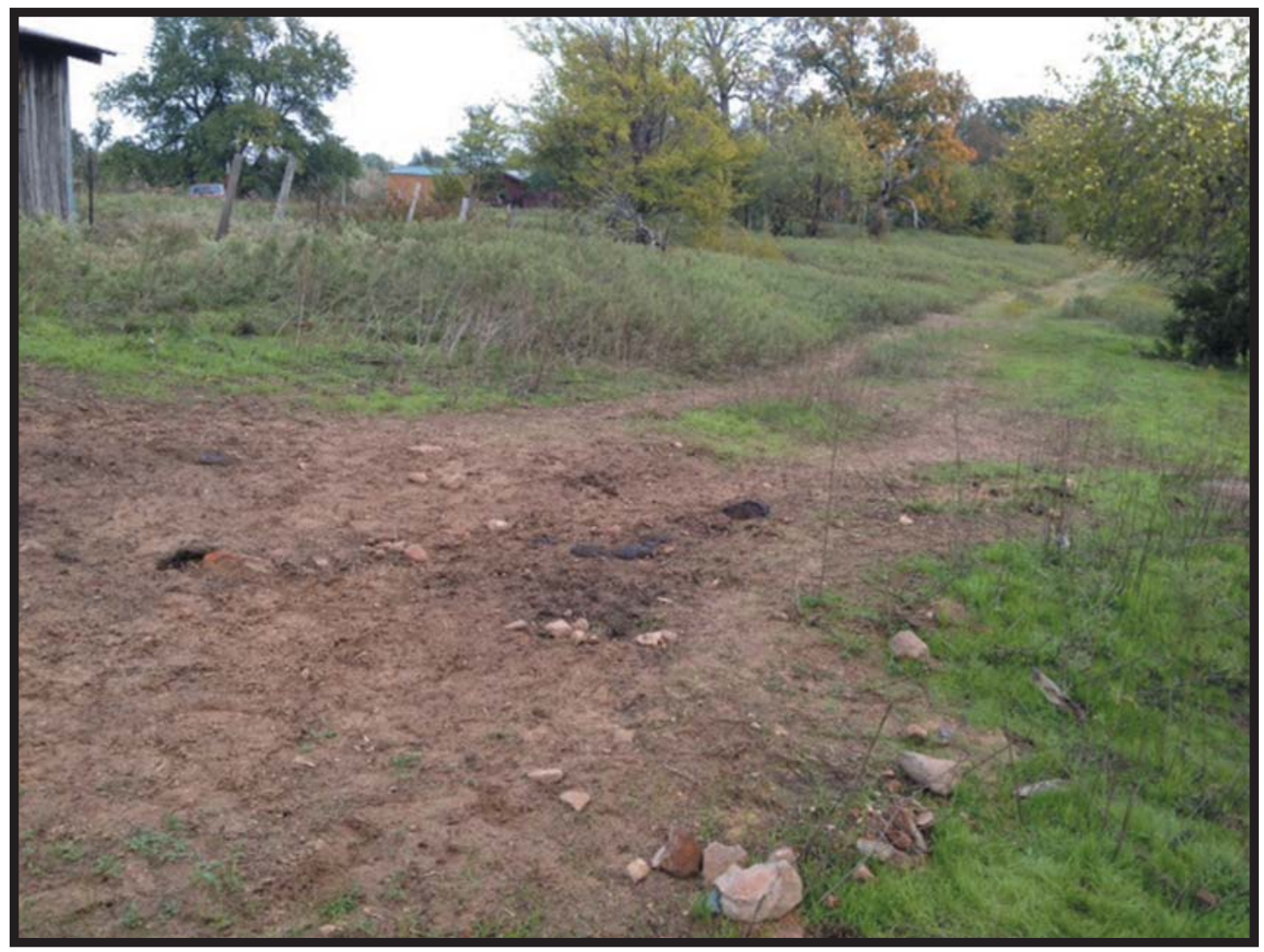

Figure 3. Area of salt lick and cattle disturbance.

\section{The Spear Points}

The nine spear points are relatively uniform in respect to their flaking characteristics as well as tool stone source material (Figure 4). All appear to have been manufactured from relatively large flake blanks. The bifacial blades exhibit moderately broad to broad, somewhat shallow, flake scars suggestive of soft hammer percussion. Lateral edges have been pressure-retouched indicating that these are finished pieces. However, the spatulate termination of Specimen Number 1 (Figure 5a) suggests that either it was not intended for use as a projectile or that it was waiting for reworking to a more pointed distal termination. All of the specimens exhibit moderately deep basal notches. Barbs resulting from the basal notching have a slightly excurvate shape with a pointed termination. Although ultraviolet spectrum light was not used to verify the tool stone source, the physical appearance of the stone is consistent with Cretaceous age material derived from the Edwards Plateau of central Texas. Although cherts in the locally available John's Valley Shale formation have similar characteristics to Edwards material, the Atoka County specimens are readily identifiable as Edwards chert. Don Wyckoff examined photographs of the ten spear points and confirmed their classification as material from the Edwards Plateau. The material colorization varies somewhat among the specimens and grades from a root beer brown to the dark blue/gray hues of the Oil Creek Edwards variety to the more common medium gray Edwards with white inclusions. Three of the pieces are broken, probably from the pressure of a cow's hoof. Most of the intact points also have some degree of lateral edge damage from cattle trampling.

Basic measurements were taken on the specimens. These include length, width at the shoulder, width at one-half the length, maximum thickness, length of the stem, width of the stem, and depth of the left and right notches (all measurements are in millimeters). Notes were also taken on the condition of the spear point and any other distinguishing characteristics. The central tendencies of the eight points are presented in Table 1 with detailed measurements for each piece presented below. 


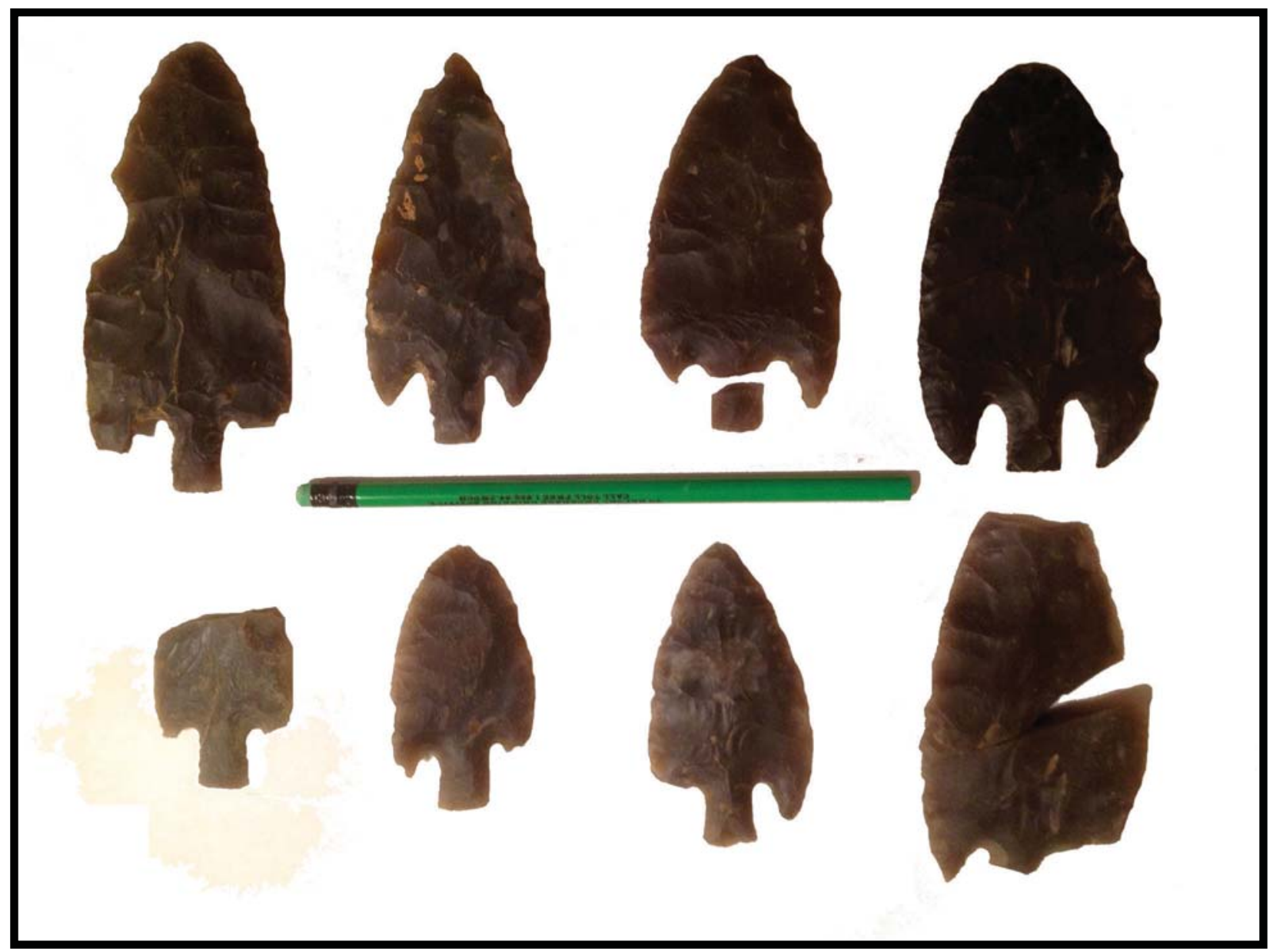

Figure 4. Eight of the nine spear points. 


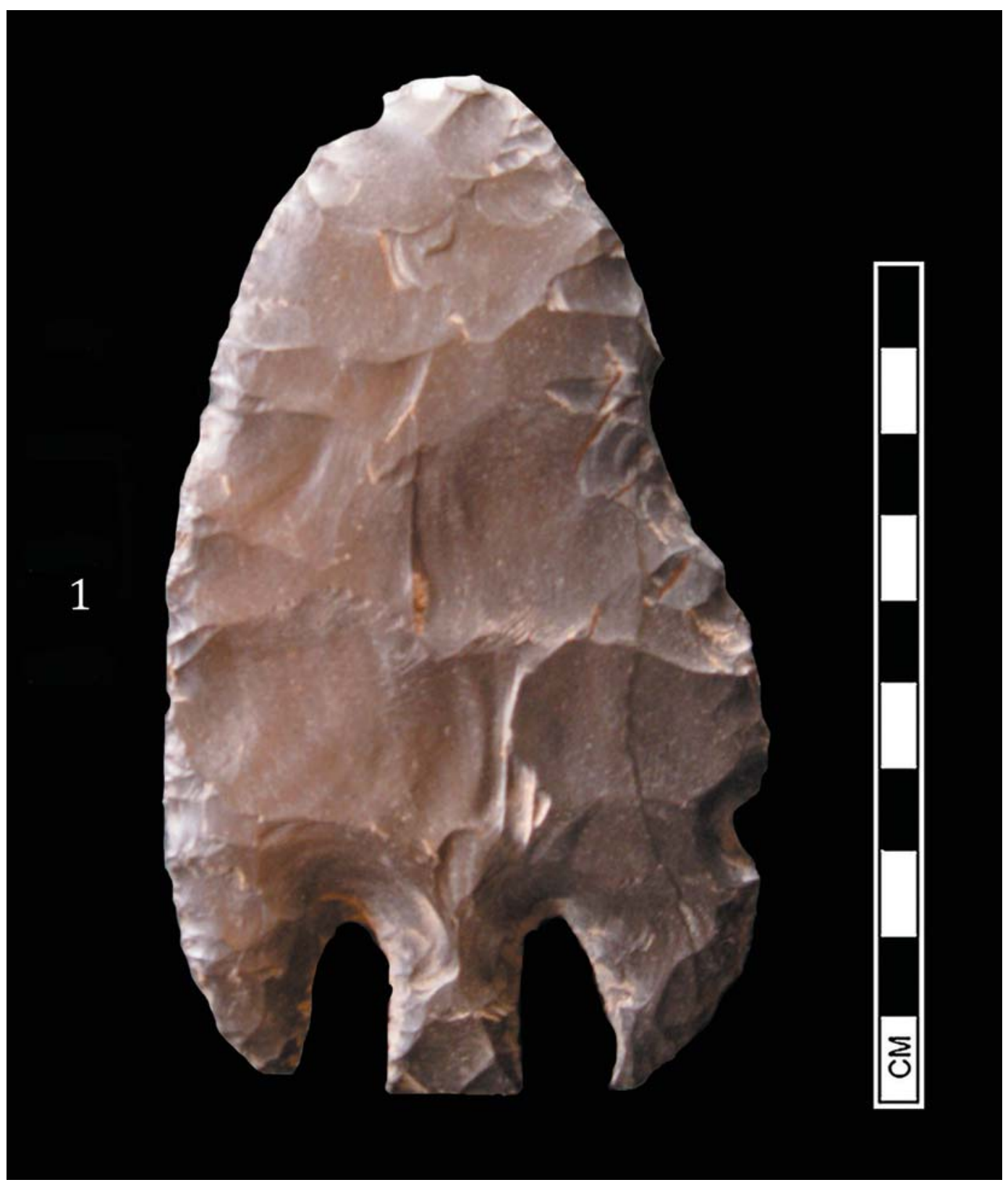

Figure 5a. Basal notched spear points, Specimen 1.

Specimen Number 1 (Figure 5a)

Length: 121.31 Width/Shoulder: 68.1 Width/1/2 Length: 65.11 Thickness: 11.74 Stem Length: 20.24 Stem Width: 15.18 Left Notch Depth: 21.03

Right Notch Depth: 21.75 Condition: complete; slight damage, right lateral edge 


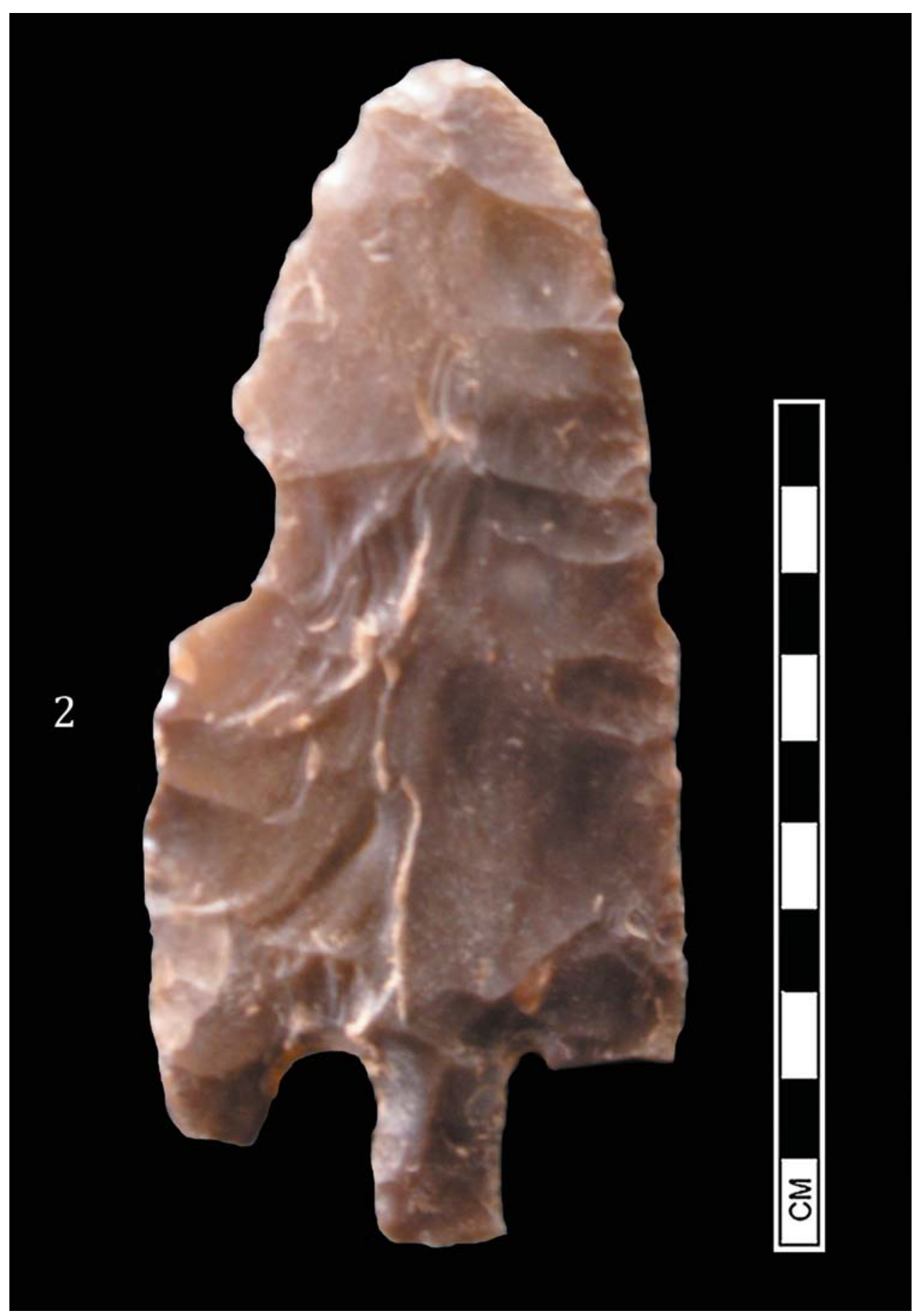

Figure 5b. Basal notched spear points, Specimen 2 .

Specimen Number 2 (Figure $5 b$ )

Length: 136.44 Width/Shoulder: 69.97 Width/1/2 Length: 56.79 Thickness: 8.82

Stem Length: 21.43 Stem Width: 14.75 Left Notch Depth: 20.98

Right Notch Depth: 21.35 Condition: complete; damage left lateral edge, right barb broken 


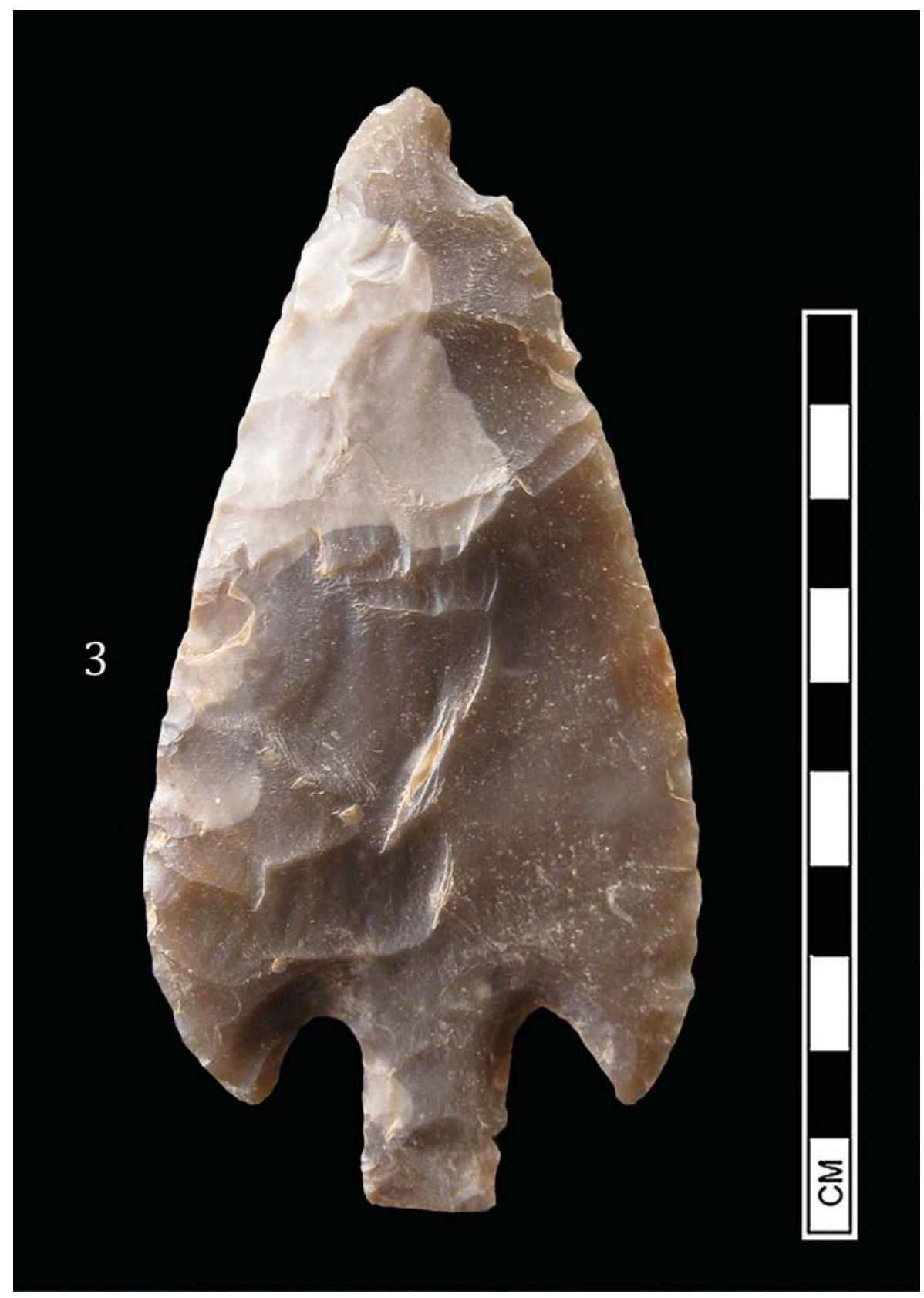

Figure 5c. Basal notched spear points, Specimen 3.

Specimen Number 3 (Figure 5c)

Length: 116.88 Width/Shoulder: 54.05 Width/ 1/2 Length: 49.76 Thickness: 8.82

Stem Length: 21.11 Stem Width: 15.29 Left Notch Depth: 15.22

Right Notch Depth: 16.59 Condition: complete; slight damage near distal termination 


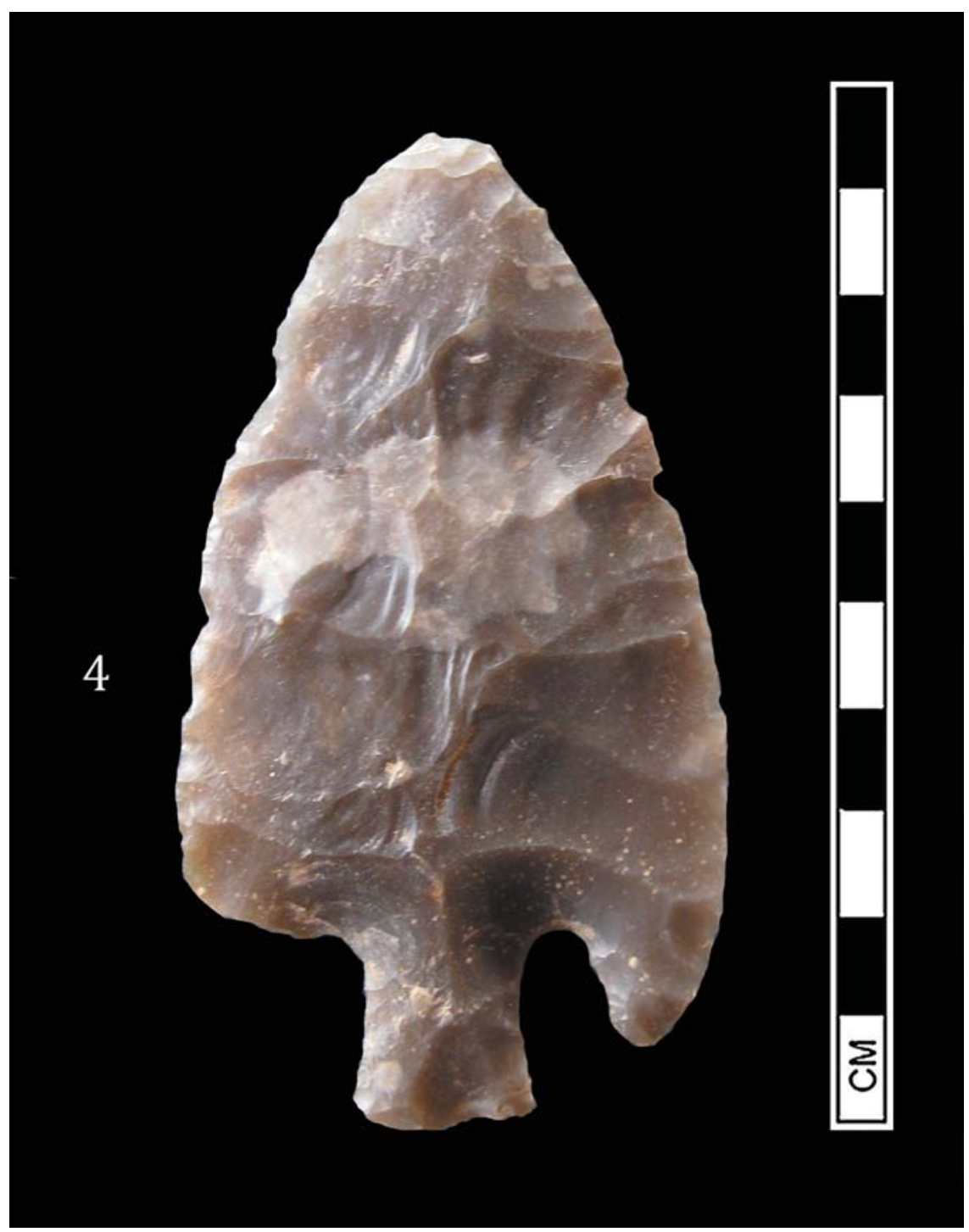

Figure 5d. Basal notched spear points, Specimen 4.

\section{Specimen Number 4 (Figure 5d)}

Length: 92.92 Width/Shoulder: 48.95 Width/ 1/2 Length: 45.62 Thickness: 8.71

Stem Length: 18.37 Stem Width: 16.88 Left Notch Depth: 15.59

Right Notch Depth: - Condition: complete; right barb broken 


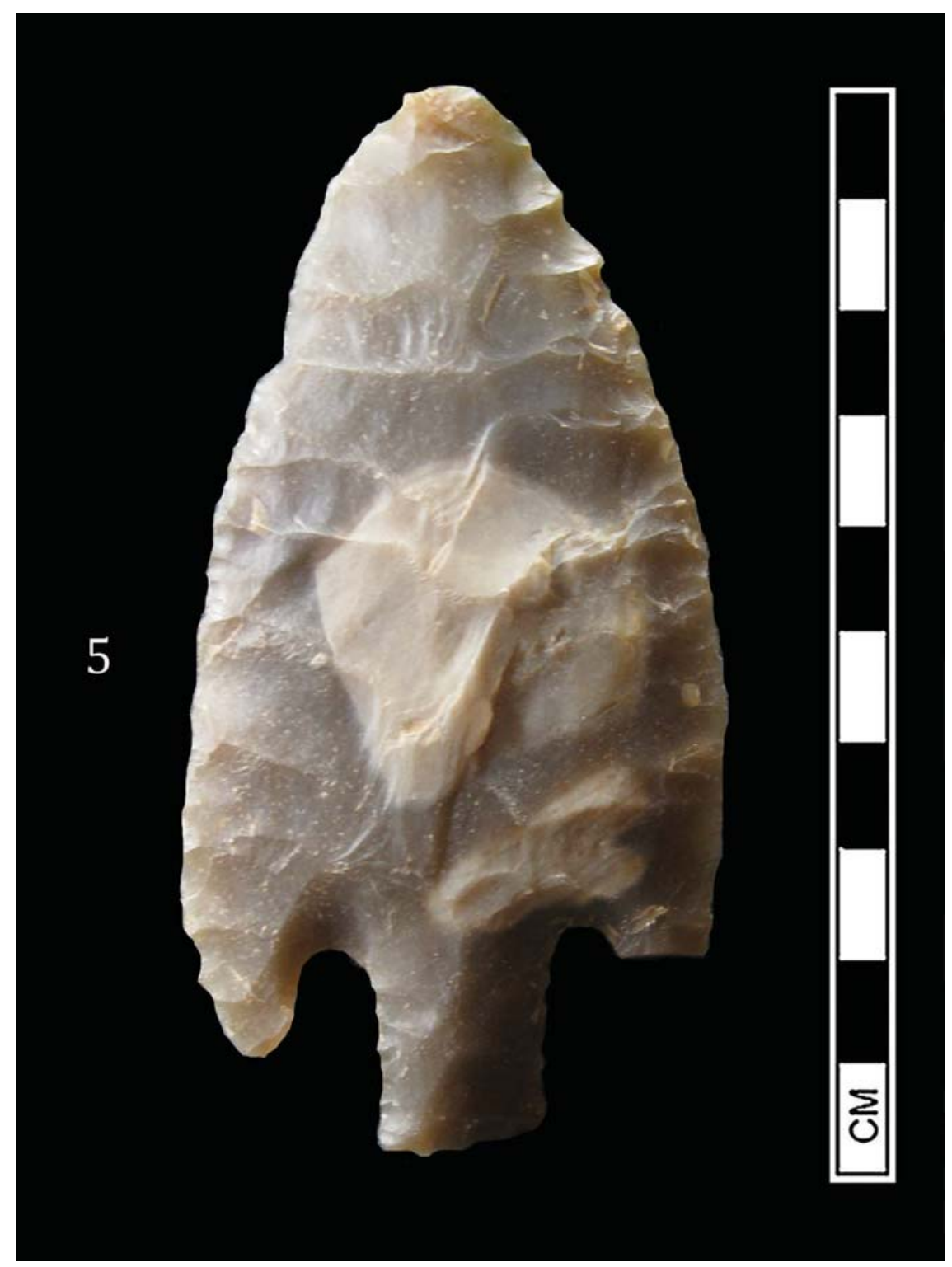

Figure 6a. Basal notched spear points, Specimen 5.

Specimen number 5 (Figure 6a)

Length: 96.47 Width/Shoulder: 46.01 Width/1/2 Length: 45.67 Thickness: 7.73

Stem Length: 19.07 Stem Width: 16.88 Left Notch Depth: 13.49

Right Notch Depth: - Condition: complete; right barb broken 


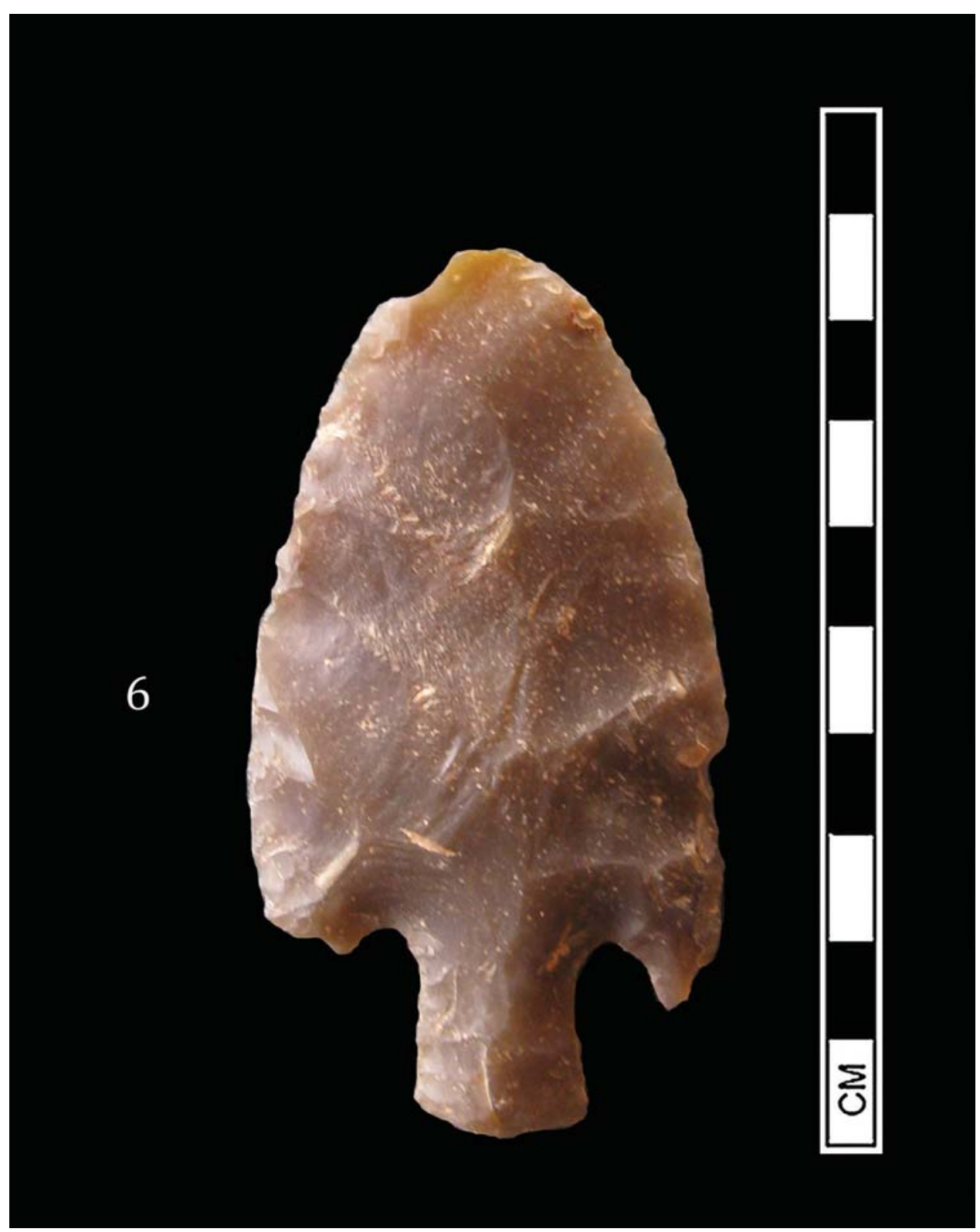

Figure 6b. Basal notched spear points, Specimen 6.

Specimen Number 6 (Figure 6b)

Length: 82.09 Width/Shoulder: 45.19 Width/ 1/2 Length: 42.5 Thickness: 8.33

Stem Length: 19.23 Stem Width: 15.45 Left Notch Depth: 12.82

Right Notch Depth: - Condition: complete; left barb broken 


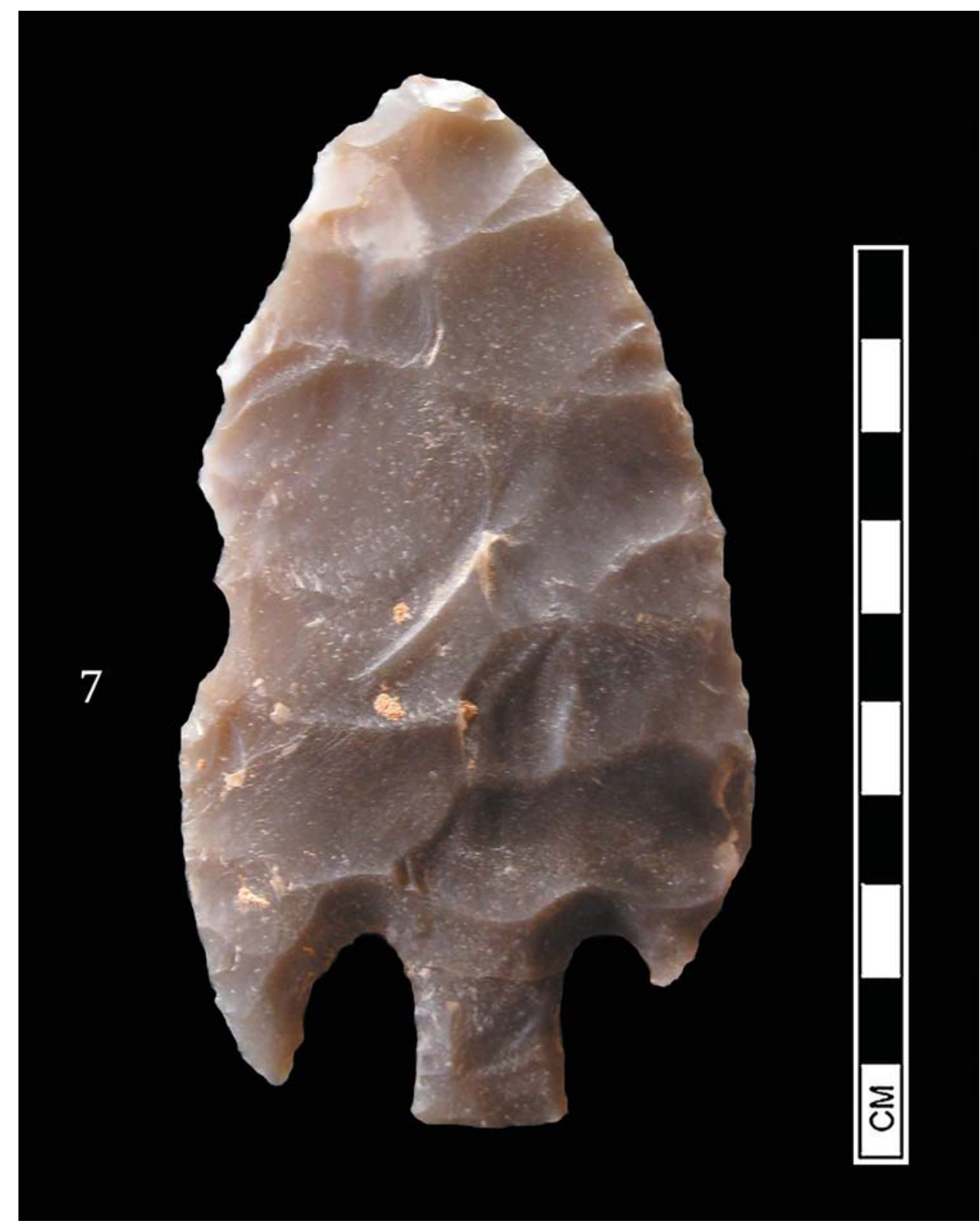

Figure 6c. Basal notched spear points, Specimen 7.

Specimen Number 7 (Figure 6c)

Length: 113.78 Width/Shoulder: - Width/ 1/2 Length: 54.66 Thickness: 10.02

Stem Length: 16.77 Stem Width: 16.55 Left Notch Depth: 16.85

Right Notch Depth:- Condition: fragmented; right barb broken, stem broken (refit) 


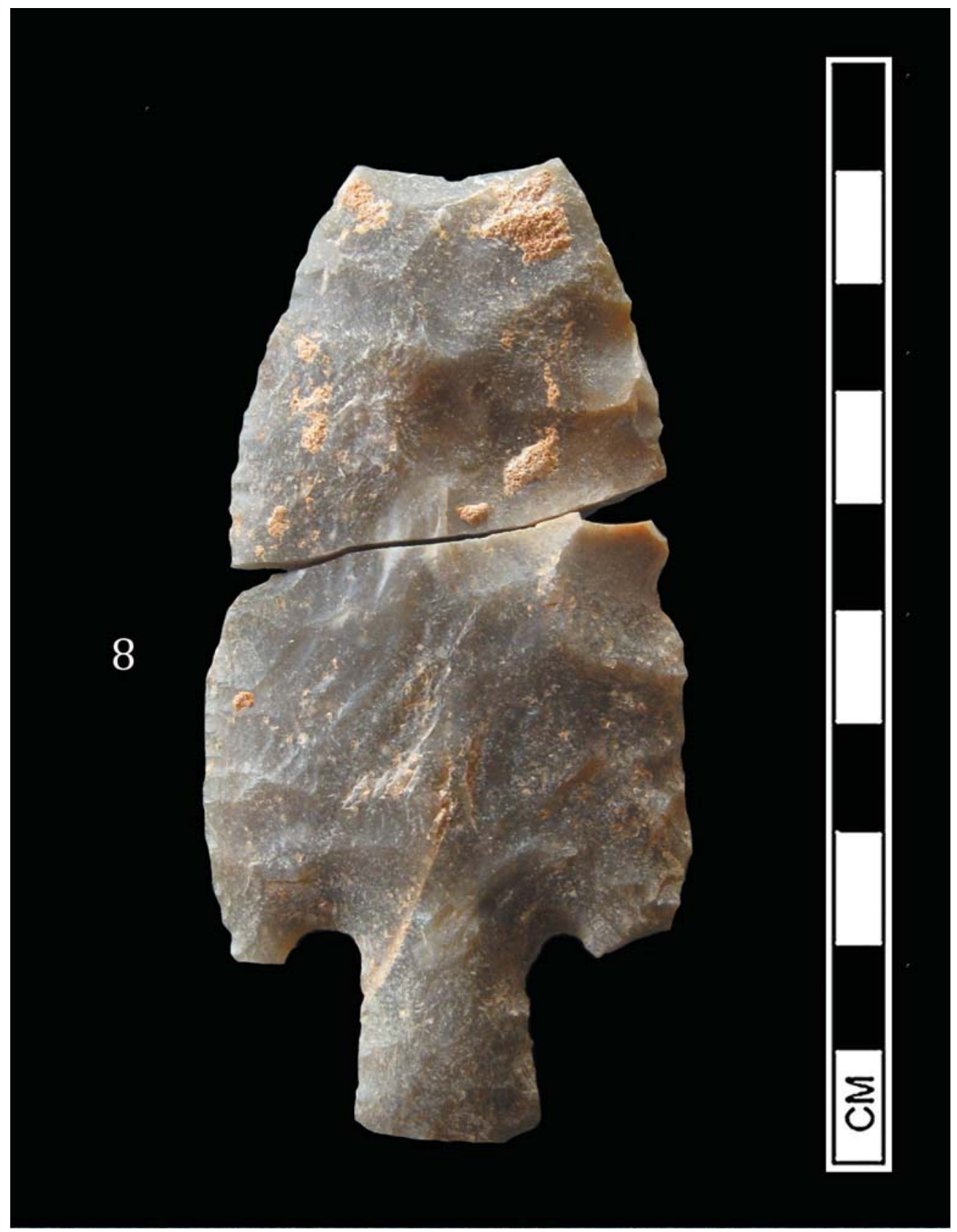

Figure 6. Basal notched spear points, Specimen 8.

Specimen Number 8 (Figure 6d)

Length: - Width/Shoulder: 90.64 Width/ 1/2 Length: - Thickness: 8.52

Stem Length: 18.73 Stem Width: 16.35 Left Notch Depth:-

Right Notch Depth: - Condition: fragmented; both barbs, midsection broken 


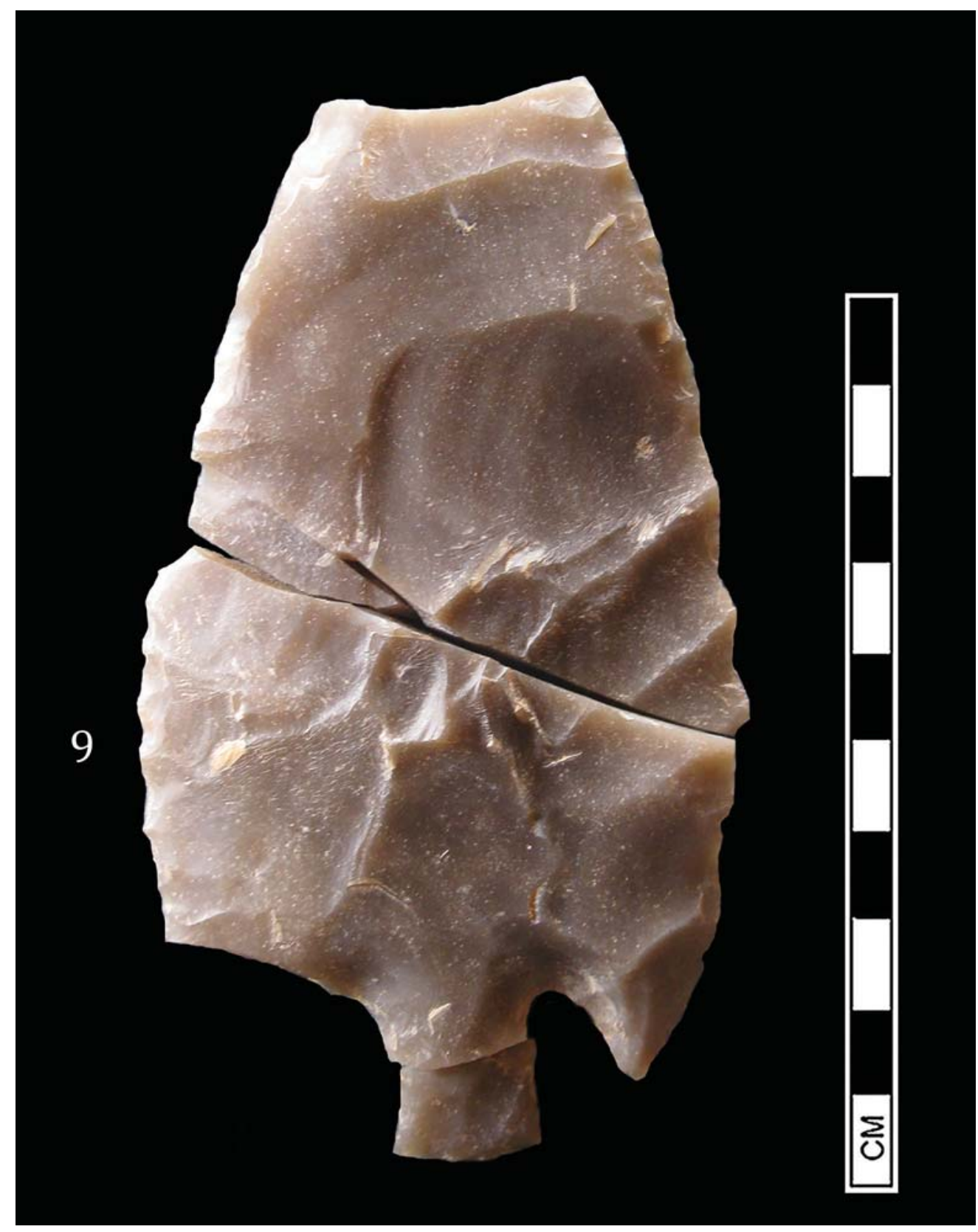

Figure 6. Basal notched spear points, Specimen 9.

Specimen Number 9 (Figure 6e)

Length: - Width/Shoulder: - Width $1 / 2$ Length: 1 Thickness: 10.53

Stem Length: - Stem Width: - Left Notch Depth: -

Right Notch Depth: - Condition: fragmented into four pieces 


\section{Discussion}

There are a number of points of discussion for the pieces described in this study. These issues pertain to stylistic attributes of the specimens and their age, to the spear point characteristics, and to the aggregation of these artifacts.

\section{Stylistic Attributes}

The Atoka County spear points represent moderately large ovate bifaces (over $10 \mathrm{~cm}$ in length and six $\mathrm{cm}$ in width) that are basally notched with moderate barbs. The stems are relatively short and only slightly elongated (a length to width ratio of 1.2). The difficulty arose when attempting to identify them with a wellknown type or style. I examined the literature for basally notched specimens from the surrounding region and found three possibilities. It would be tempting to incorporate them into the well-documented Calf Creek type. Calf Creek spear points and their synonymous types in Texas (Andice and Bell) are large ovate bifaces with deep basal notches and pronounced barbs (Wyckoff 1994). Calf Creek, Bell, and Andice are generally acknowledged as dating to the Middle Archaic of some 5000 years ago. The Atoka County specimens fall within the range of Andice points, (Chris Lintz, personal communication). They also display many of the manufacturing trademarks of the Calf Creek, well-defined basal notches and pronounced barbs, as well as exhibiting the refined soft hammer percussion signature of Calf Creek spear points. However, the stem is considerably shorter in length and narrower than most Calf Creek, Bell, or Andice spear points and the barbs do not exhibit the deep notches characteristic of these Middle Archaic period specimens (Wyckoff 1994).

Another spear point exhibiting basal to corner notches and an ovate form is the Marshall (Bell 1958:44). Marshall point basal notches are not as deep as those observed for Calf Creek, have less pronounced barbs, a broader stem, and are somewhat smaller. They also frequently tend to being corner-notched rather than basally notched. The Marshall spear point is generally associated with the Late Archaic /Early Woodland time period of some 2000-4000 years ago. The Atoka County pieces do resemble the more basally notched Marshall although they exhibit deeper basal notches, have narrower stems, and are considerably larger.

A third basally notched spear point documented for the region is the Ouachita or Little River spear point (Perino 1976, 1980). Although not extensively documented, limited data point to the Ouachita being a large biface with moderately deep basal notches and barbs that resemble those of the Atoka County specimens. A cache of four Ouachita points manufactured of quartzite was found in McCurtain County, Oklahoma (Perino 1980). Another cache of five Ouachita points, also made of quartzite was found in Feature 4 at the Edward Abbey Memorial site (34AT268) in McGee Creek Reservoir (Ferring 1994:292). Ferring (1994) considers the feature holding the cache as being associated with Component II at the site that dates to the Late Archaic period (2500-2000 years ago). The Edward Abbey Memorial site is approximately $33 \mathrm{~km}$ southeast of the cluster of artifacts discussed here. It appears that the Atoka County specimens most closely resemble the Ouachita spear point. They have somewhat narrower stems, but this could be a function of the Atoka County specimens being manufactured from the higher quality Edwards chert rather than Ouachita Mountains quartzite.

From this comparative analysis, the Atoka County artifacts are Ouachita/Little River spear points that date to the Late Archaic period. It is also notable that Ouachita points have been documented in caches from southeastern Oklahoma.

Based on their stylistics characteristics, it is tempting to argue that the same individual manufactured all of the points. All nine spear points exhibit the same refinement in blade and stem preparation. A 
correlation (Pearson's r) of total length and width of the point at half the length resulted in an r-value of .81. This suggests that flake length was probably a strong determining factor in width of the blade (Figure 7). To better understand the shape of the Ouachita spear point shape, a ratio of width at half the length divided by total length was used as a proxy for shape (Figure 8). Higher ratios would reflect a broader blade and a lower ratio would result in a more narrow blade form. Specimen \#1 has the widest blade whereas Specimens \#2 and \#3 have more narrow blades. Specimens \#4-7 are clustered around .50. But, they all fall within about a 10-point range (.42-.53). Thickness of the specimens is somewhat more variable (Figure 9). It would appear that there is considerable homogeneity among the nine pieces. If an individual knapper were responsible for their manufacture, they are probably making a conscious effort to control for variation. Of course, the existing variation may simply reflect differential size of the tool stone blank, which would affect the product outcome.

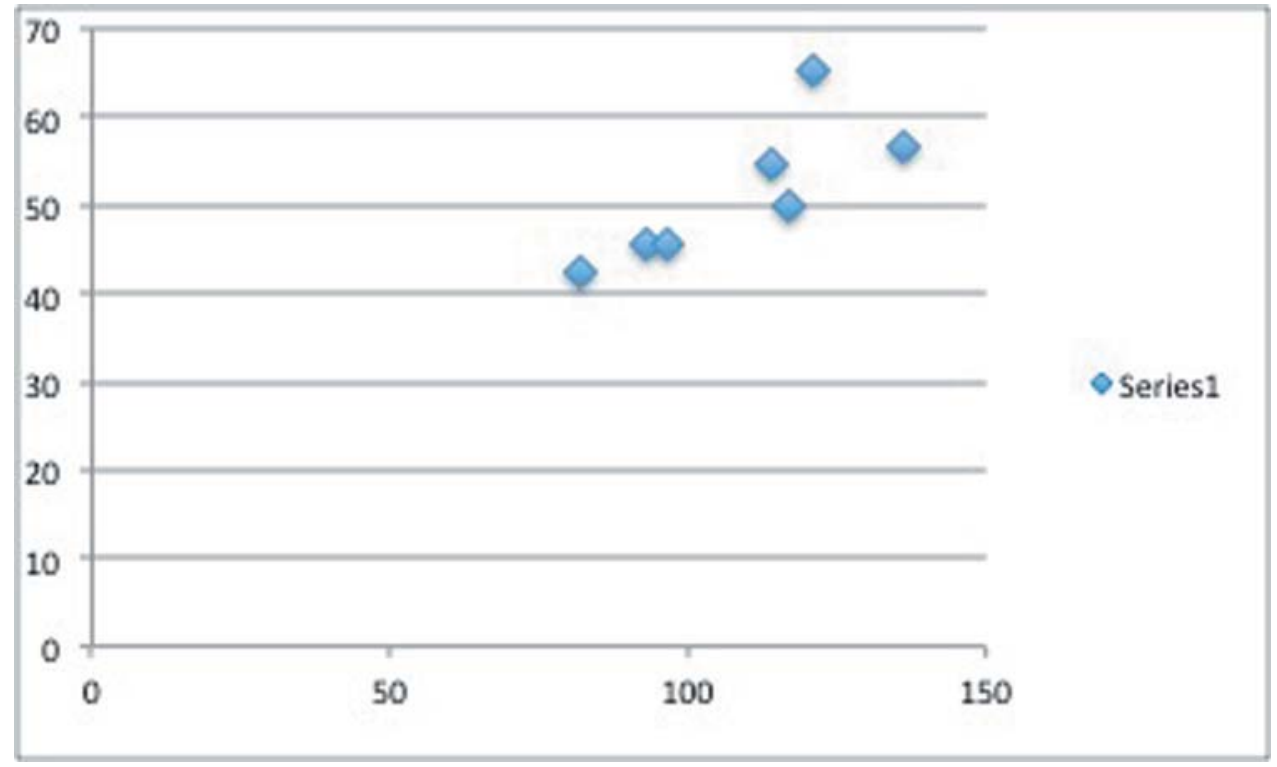

Figure 7. Graph plotting length and maximum width of spear points from Atoka County ( $\mathrm{x}$ axis = length; $\mathrm{y}$ axis $=$ width at $1 / 2$ length)

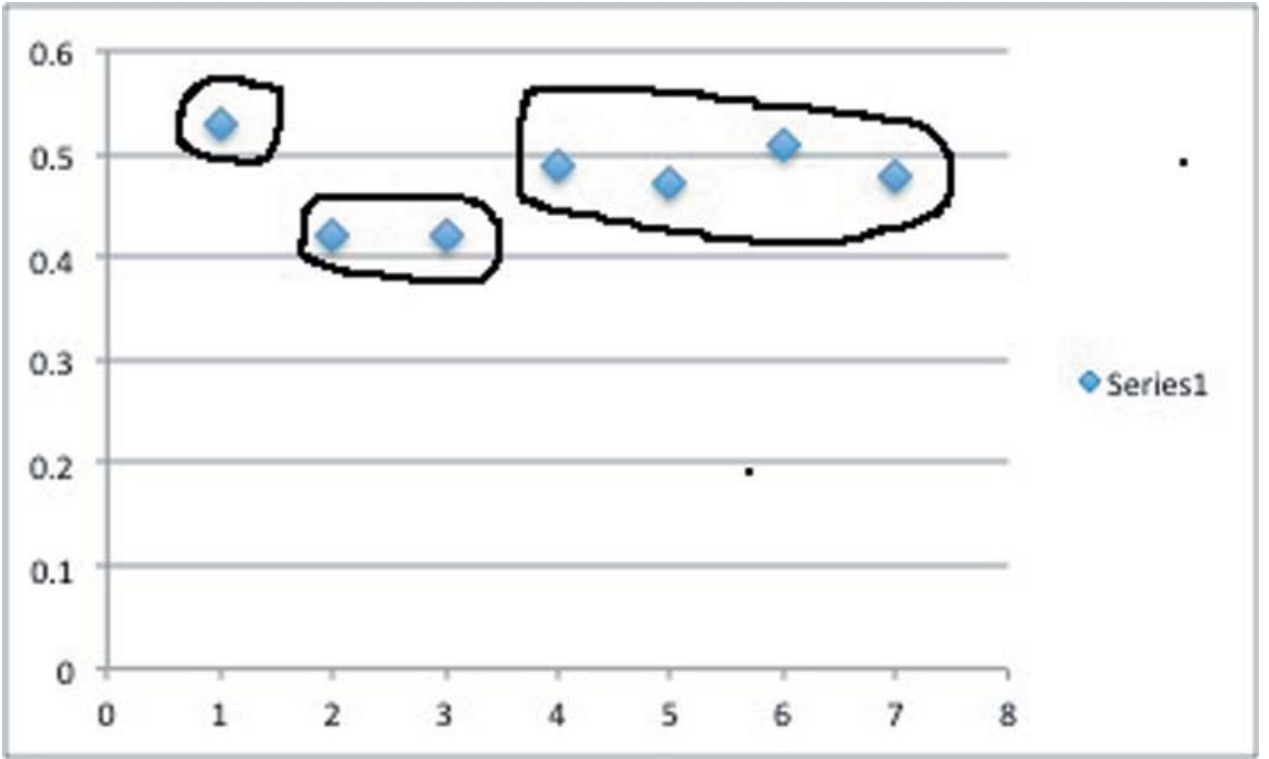

Figure 8. Ribbon graph plotting shape of Atoka County spear points $(\mathrm{x}$ axis $=$ specimen number; $y$ axis = ratio of width at $1 / 2$ length divided by length) 


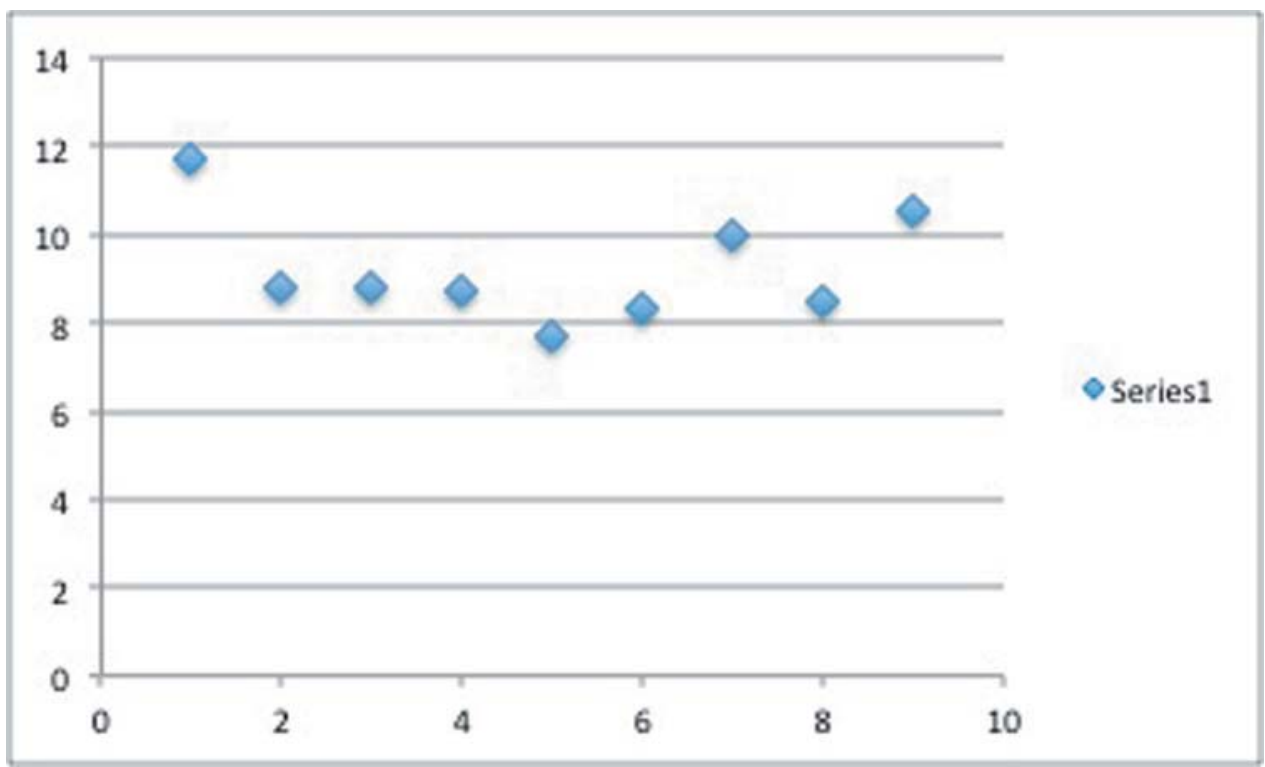

Figure 9. Ribbon graph plotting thickness of Atoka County spear points ( $\mathrm{x}$ axis= specimen number; $\mathrm{y}$ axis $=$ maximum thickness).

It would have been interesting to compare the Ouachita spear points from the Atoka County aggregate to those documented by Ferring (1994) and Perino (1980). However, it proved difficult to identify the five Ouachita spear points in the data tables for the Edward Abbey Memorial site (Ferring 1994: 599-616) and Perino (1980) provided no measurement data for the four McCurtain County specimens.

\section{Spear Point Characteristics}

Spear points used during the Archaic period were multi-purpose tools. They served as a weapon (a projectile), were used as a knife to butcher game, and to occasionally gouge and scour items. These multiple uses would ultimately lead to dulling of the lateral edges of the spear point that would require sharpening. Sharpening was a continual process and ultimately led to exhaustion of the tool. Alternatively, they were sometimes retooled for use as a scraper, graver, or drill after exhausting the blade. In other instances, the tool would break during use or sharpening also resulting in recycling to another purpose. Typically, Archaic spear points reflect this range in maintenance activities. Many exhibit reduction in the width of the blade due to continuing maintenance. Others are transformed into scrapers, gravers, and drills as noted above. The Ouachita specimens in this study are somewhat unique in that they display only minimal maintenance. The blade or body for seven of the specimens exhibits excurvate lateral edges, reflecting a minimal amount of sharpening or maintenance. The other two (Specimens 2 and 8) have somewhat more triangular blade shapes, but are not extensively reworked. Examination of the lateral edges using a hand lens revealed some maintenance and/or final edge treatment. However, the right barb is missing from many of the pieces. This breakage pattern could be a function of use as a knife. It might also reflect the cattle trampling that damaged many of the spear point, but it would be unusual that this disproportionately affected the right barb. The nine points appear to represent an aggregate of tools that were recently manufactured and had not experienced a great deal of use. What cannot be resolved is whether this group of points was planned for future domestic use (hunting, butchering of game, etc.) or for some non-domestic purpose. 


\section{Artifact Aggregation}

Artifact aggregation can be expressed in a number of ways. There may be a large volume of associated material discarded in midden contexts. You can also have aggregation of a large number of artifacts derived from a particular activity, for example, tool manufacture and knapping debris. Another artifact aggregate results from the planned placement of artifact clusters at a given location. This is what takes place with caching activity and also with funerary offerings to a deceased member of the society. Attention is focused on caching as an expression of artifact aggregation.

There have been a number of caches or cache-like artifact aggregations documented for the Archaic period in Oklahoma. Calf Creek groups are particularly noted for their caching behavior (cf., Primrose [34MR65], Wyckoff, Neal, and Duncan 1994; and Stilman Pit [34MR71], Bartlett 1994). The Primrose and Stilman Pit sites represent locations where large blanks were stored for future manufacture. Both sites contain large flake blanks, unfinished bifaces, completed Calf Creek spear points, and some debris from tool manufacture. They also show some evidence of at least temporary use for habitation.

There are also caches or apparent caches related to the Ouachita spear point. As previously noted, five Ouachita/Little River spear points were found in Feature 4 at the Edward Abbey Memorial site (34AT268). These were in a pit associated with vertically positioned sandstone slabs and cobbles, some $42 \mathrm{~cm}$ below surface (Ferring 1994:290-292). Site 34AT268 was one of the most intensively occupied sites documented at McGee Creek Reservoir. The other cache comes from McCurtain County near the juncture of Cypress Creek and Little River (Figure 10; Perino 1980:9). Weyerhaeuser pine planting exposed this cluster of four spear points made of Ouachita Mountains quartzite. There was no indication as to whether these were an isolated occurrence or found within a residentially used locale. However, there are numerous recorded sites in the immediate vicinity, making it likely that these points were also from a residential site context.

The documented cache-like collections of material can be interpreted as a logistical function. The Primrose and Stilman Pit sites contained material that was stockpiled for future use in spear point manufacture. Considering that large blanks were necessary for preparation of the relatively large Calf Creek point, it was not cost-effective to transport the tool stone, assuming that Calf Creek groups were highly mobile hunters and gatherers. It would have been much more practical to store the material at a marked location and return periodically to re-tool. The cache of Ouachita spear points found at the Edward Abbey Memorial site was intentionally placed in the pit. Assuming that the group was nomadic and this site was one in a series on a seasonal round, the cache may have been left for a return visit. A similar practice is also possible for the McCurtain County Ouachita spear point aggregate although this is only an inference based on the presence of a number of nearby residential sites.

The aggregate from Coal County differs markedly in that only complete spear points were present; there was no evidence of bifacial or flake blanks, unfinished bifaces, or other tools forms. The location also holds no suggestion of use as a residential site-even one of temporary nature, and no evidence of burial association. 


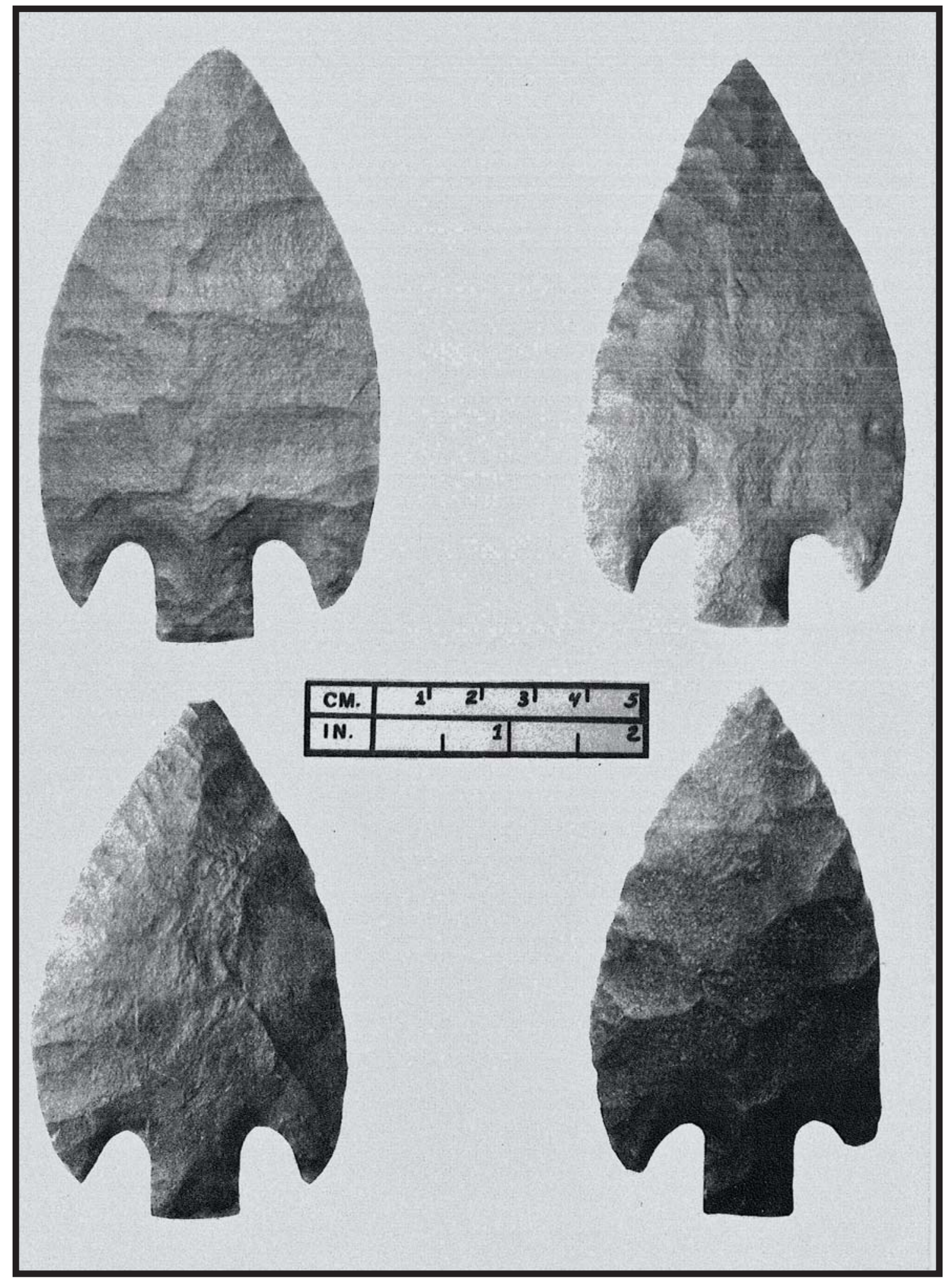

Figure 10. Four Ouachita spear points found in McCurtain County. 
Thus, the cluster of Ouachita spear points described in this study does not have a logistical function or a funerary context. Considering that these are finished pieces, why not simply include them among the group's gear? The nine spear points would not represent significant baggage in respect to transport. It could be argued that perhaps these were funerary offerings. However, there was no suggestion of human remains or even a pit-like feature at the location. And, there was also no indication that this was a residential place. There is, however, another consideration. In an article published a number of years ago, I discussed the concept of planned versus unplanned abandonment (Brooks 1993). While this discussion focused on village farming societies and their use/abandonment of dwellings, the concept can be expanded to that of artifact aggregates. In contexts such as the one outlined in this study, artifact aggregates are often considered to be caches. Caching is a planned activity. But, what if the artifact aggregation was an unplanned event? The Atoka County Ouachita spear point cluster could have been contained in a leather pouch that was dropped or otherwise lost during the group's travel. It would have been an unplanned event, which would account for the absence of a functional explanation for the spear point's seemingly absence of a logistical context. The Ouachita spear point cluster was found only a few inches below ground surface. It is plausible that the points were lost by a band member and were gradually and shallowly buried by downslope movement of soil (and perhaps wind-blown deposits as well). This explanation would account for the differences from what is typically found in a cache.

That being said, I cannot totally exclude these caches having some meaning within the context of ritual. Currently, most of the documented Ouachita/Little River spear points have been found as aggregates. I visited the Museum of the Red River hoping to find additional details on the McCurtain County "cache" but apparently Greg Perino did not leave this file. The museum collections were also examined for additional examples of Ouachita/Little River spear points. Two Ouachita points of Ouachita Mountains quartzite were identified, although their provenance is unknown. Thus, it is unclear whether they were found together or from separate locales. Two very large pieces made of unheated Novaculite identified as Little River points were examined as well (Figures 11-12). Although their provenance is not specifically known, they were apparently found in McCurtain County. Examining the Novaculite specimens, three thoughts surfaced. First, the two pieces are so similar in size and material that they were potentially from the same site. Second, the spear points are sufficiently large that I doubt that they were intended for domestic use. The two spear points are $140 \mathrm{~mm}$ long, $94 \mathrm{~mm}$ wide and $185 \mathrm{~mm}$ long, $81.8 \mathrm{~mm}$ wide. The somewhat spatulate distal termination would not be particularly functional as a projectile although they would be functional as knives. Third, I question whether Oauchita points and Little River points bear much of a relationship other than being basally notched. Although Greg Perino suggested a relationship in his article on the Ouachita points (Perino 1980), the two styles appear to be substantially different. Little River spear points are extremely large, sufficiently so to be viewed as ceremonial blades. Their manufacture also appears to lack the refinement of Ouachita points, although this could be a function of the coarse-grained nature of unheated Novaculite. We should be cautious in identifying Ouachita and Little River spear points as synonymous styles. 


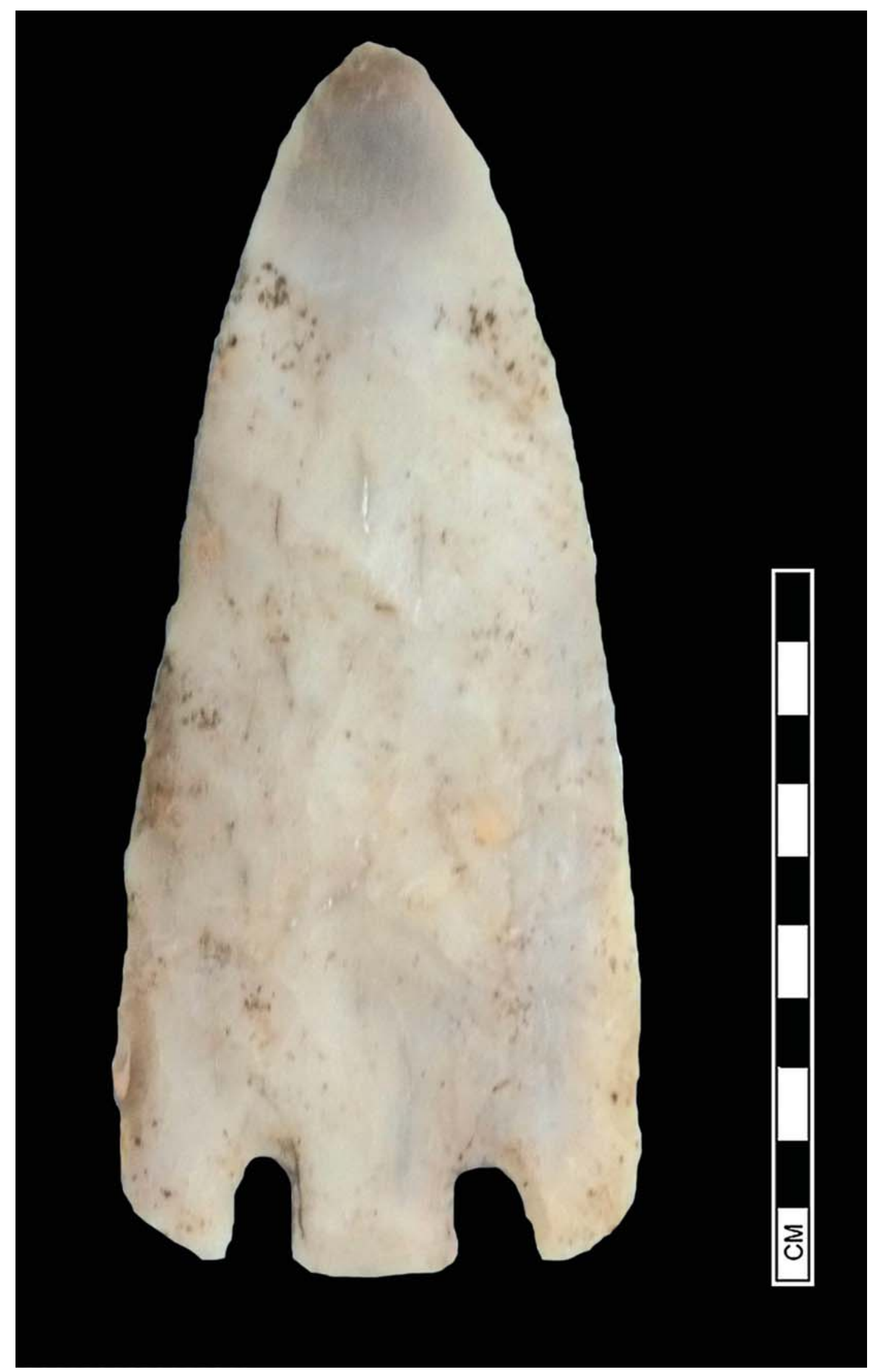

Figure 11. One of two Little River spear points identified for McCurtain County. 


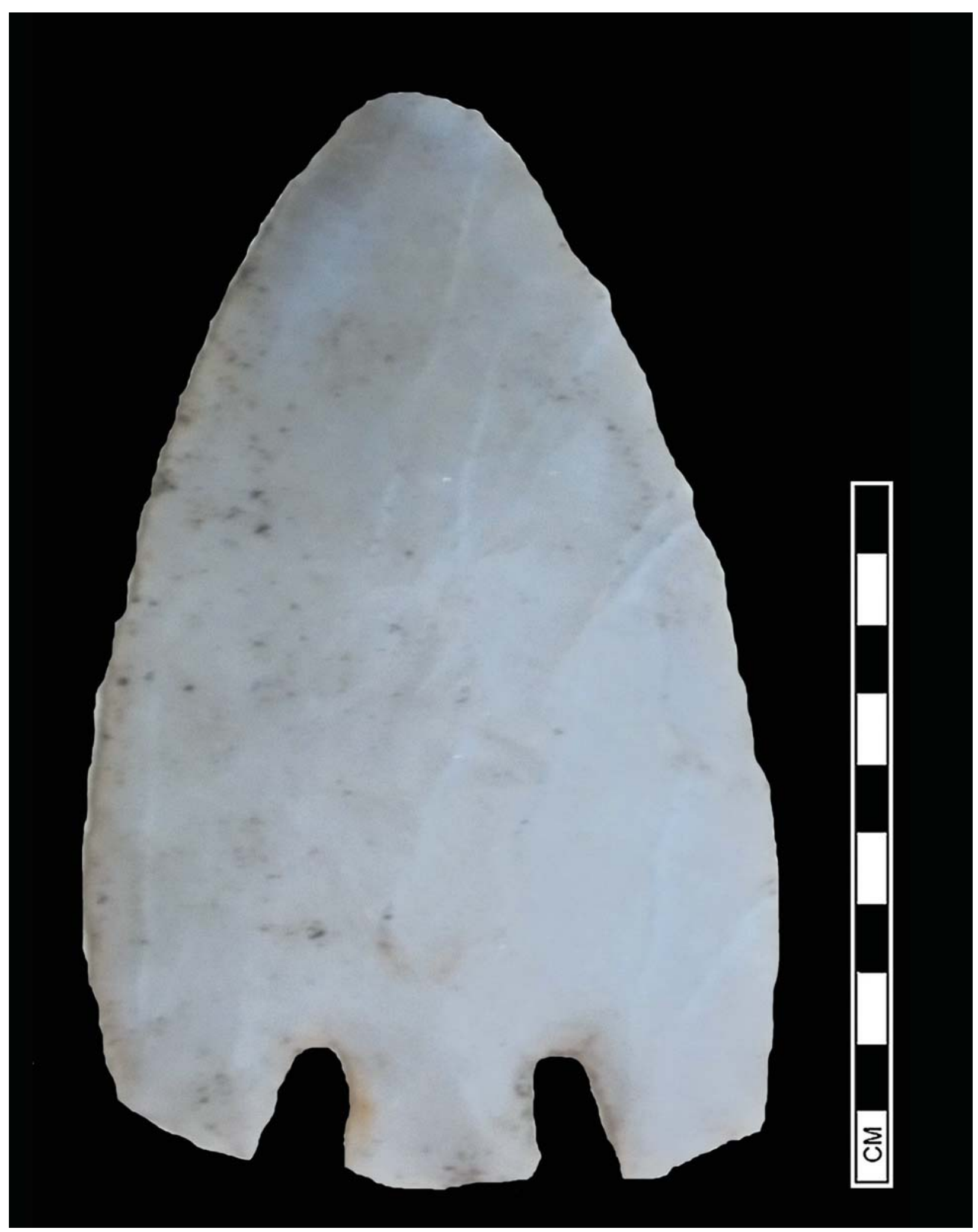

Figure 12. Two of two Little River spear points identified for McCurtain County. 


\section{Concluding Comments}

An aggregate of spear points from a locale in northern Atoka County has provided some new insights on the Ouachita, a poorly known style that dates to the Late Archaic period of some 2000-2500 years ago. Obviously, an isolated cluster of spear points presents constraints on the substantive information that can be gleaned from analysis. In this study, I have added to the data concerning Ouachita spear point size and morphology. This is also the first group of these spear points to be documented that were manufactured from a non-local tool stone (Edwards chert). The analysis also provided some understanding of the mechanics involved in their manufacture. From a behavioral perspective, study of this aggregate of points revealed that they were relatively unused tools. Within the context of the find, the utilization of the spear points is problematic: were they intended for domestic or non-domestic purpose? Perhaps the most telling finding of this study is that aggregates of spear points should not always be interpreted as caching activity. Caching should be studied as the consequence of group or individual activity, not as an activity in itself. If you examine artifact clusters such as the Atoka County spear points from the perspective of caching as a consequence of planned activity, some may not fit the caching model and be a result of other less planned actions. A question that awaits further study and perhaps resolution is whether these aggregates of Ouachita/Little River spear points represent caches used in ritual or have intended ritualistic purpose.

\section{Notes}

Acknowledgements: I am very grateful that our family from Atoka County brought their finds to my attention. The Ouachita spear points and their context have resulted in some interesting questions concerning aggregates of finished items and their purpose. Thanks are also due to Chris Lintz for sharing his database on caches for comparative purposes. Finally, I wish to thank the two reviewers for Caddo Archeology Journal that helped improve the article's clarity and catch some of the instances where the author's thought processes were ahead of his typing. 
Bell, Robert E.

\section{References Cited}

1958 Guide to the Identification of Certain American Indian Projectile Points. Special Bulletin No. 1, Oklahoma Anthropological Society, Norman, Oklahoma.

Bartlett, Robert

1994 The Calf Creek Component at the Stilman Pit Site (34MR71) and its Relation to Calf Creek Caching Strategy. Bulletin of the Oklahoma Anthropological Society XL: 69-90.

Brooks, Robert L.

1993 Household Abandonment Among Sedentary Plains Societies: Behavioral Sequences and Consequences in Interpretation of the Archaeological Record. In Abandonment of Settlements and Regions: Ethnoarchaeological and Archaeological Approaches, edited by Catherine Cameron and Steve A. Tomka, pp. 178-190. Cambridge University Press, New York.

Ferring, Reid (editor)

1994 Prehistoric Archaeology at McGee Creek Reservoir, Atoka County, Oklahoma: Sites Along McGee and Potapo Creeks and Tributaries. Volume V, Part I, McGee Creek Archaeological Project Reports, University of North Texas, Institute of Applied Sciences, Denton.

Hoagland, Bruce W.

2006a Vegetation. In Historical Atlas of Oklahoma, edited by Charles Robert Goins and Danney Goble, pp. 24. University of Oklahoma Press, Norman.

2006b Soils. In Historical Atlas of Oklahoma,edited by Charles Robert Goins and Danney Goble, pp. 8. University of Oklahoma Press, Norman.

Johnson, Kenneth S.

2006 Geomorphic Provinces. In Historic Atlas of Oklahoma, edited by Charles Robert Goins and Danney Goble, pp. 4. University of Oklahoma Press, Norman.

Perino, Gergory

1976 A New Point Type, the Little River Point. Central States Archaeological Journal 24 (2): 1

1980 The Ouachita Point, A New Point Type for Southwest Arkansas and Southeast Oklahoma. Bulletin of the Oklahoma Anthropological Society 29:9-11.

Wyckoff, Don G.

1994 Introduction to the 1991 Bulletin. Bulletin of the Oklahoma Anthropological Society XL: 1-8.

Wyckoff, Don G., William L. Neal, and Marjorie Duncan

1994 The Primrose Site, 34MR65, Murray County, Oklahoma. Bulletin of the Oklahoma Anthropological Society XL: 11-68. 